\title{
KAJIAN PENERAPAN BUDIDAYA PADI SRI DARI ASPEK SUSTAINABLE AGRICULTURE
}

\author{
Akhmad Jani Masyhudi *), Wenny Mamilianti ${ }^{*}$ \\ ${ }^{*}$ Program Studi Agribisnis Fakultas Pertanian Universitas Yudharta Pasuruan \\ Email : fapertayudharta@yahoo.com
}

\begin{abstract}
ABSTRAK
Permasalahan yang ada adalah apakah budidaya SRI yang dilakukan oleh petani sudah bisa menjaga kelestarian lingkungan khususnya kesuburan tanah/ lahan?.Tujuan dari penelitian ini adalah (a) mengetahui pengaruh sumberdaya lokal atau faktor-faktor produksi dalam budidaya SRI terhadap produksi padi ( kompos, MOL, bibit, tenaga kerja, air), (b) mengetahui dampak budidaya SRI terhadap pendapatan petani, (c) mengetahui dampak budidaya SRI terhadap lingkungan dengan indikator kandungan NPK dan agregat tanah (keremahan). Hasil yang dicapai menunjukkan bahwa Dari pelaksanaan penelitian ini dapat disimpulkan bahwa : faktorfaktor produksi yang berpengaruh pada usahatani padi dengan budidaya SRI adalah tenaga kerja dalam keluarga (TKDK), tenaga luar keluarga (TKDL), bibit, kompos, MOL dan pupuk anorganik. Budidaya padi SRI memberikan keuntungan yang signifikan, rata-rata pendapatan per hektar petani SRI lebih besar daripada petani Non SRI. Perbedaan ini secara statistik nyata pada tingkat signifikansi $1 \%$. Perbedaan pendapatan ini disebabkan jumlah produksi pada usahatani SRI lebih tinggi sehingga penerimaannya lebih besar meskipun dilihat dari segi biaya selisihnya hanya sedikit. Dilihat dampak dari usahatani SRI terhadap kandungan NPK tanah pada lahan yang telah menerapkan budidaya SRI lebih dari 4 kali musim tanam atau berkisar 1 tahun lebih menunjukkan kandungan $\mathrm{N}$ organik yang tinggi yaitu 0,638 berkisar antara 0,51 0,75 sedangkan NON SRI 0,1159 yaitu rendah atau berkisar antara 0,1-0,2. Ini jelas menunjukkan bahwa budidaya SRI dapat memperbaiki kandungan nutrisi tanah yang sangat bermanfaat terhadap tanaman.
\end{abstract}

Kata Kunci : Budidaya Padi SRI, Sustainable Agriculture

\begin{abstract}
The issue is whether the SRI cultivation by farmers had been able to preserve the environment, especially in soil fertility or soil?. Purpose of this study was (a) determine the effect of local resources or factors of production in the SRI cultivation of paddy production (compost, MOL, seedlings, labor, water), (b) determine the impact of SRI cultivation on farmers' income, (c) determine the impact on the environment SRI cultivation with indicator and nitrogen, phospor, potassium content of soil aggregates (crumb). The results obtained show that the implementation of this study it can be concluded that: the factors that influence the production of paddy with SRI cultivation was labor in the family, non-family labor, seeds, compost, MOL and inorganic fertilizers. SRI paddy cultivation provides a significant advantage, the average income every hectare of farmers SRI greater than non- SRI farmers. This difference was statistically significant at $1 \%$ significance level. The difference was due to the amount of revenue production at higher SRI farming that despite greater acceptance in terms of the cost difference is only slight. Seen against the impact of SRI farming nitrogen, phospor, potassium content of soil on land that has been applying SRI cultivation was more than 4 times a growing
\end{abstract}


season ranges from 1 year or more indicates high organic $\mathrm{N}$ content ranged from 0.51 to 0.75 was 0.638 , while NON SRI 0.1159 was low or ranged between 0.1 to 0.2 . This clearly shows that the SRI cultivation can fix the nutrient content of the soil that were beneficial to plants

Keyword : SRI rice cultivation, sustainable agriculture

\section{PENDAHULUAN}

Peningkatan produktivitas padi merupakan kunci dalam membangun kemandirian pangan di Indonesia. Upaya ini bukan saja dihadapkan pada batas kemampuan teknologi dan pengaturan yang ada selama ini dengan permasalahan sosiokultural yang menyertainya namun juga dituntut untuk dapat memenuhi kriteria ramah lingkungan dan mutu produk yang lebih sehat. Kualitas lingkungan mempunyai hubungan kausal dua arah dengan tingkat pendapatan. Peningkatan kualitas lingkungan dapat meningkatkan tingkat pendapatan petani dan sebaliknya peningkatan tingkat pendapatan petani dapat meningkatkan kualitas lingkungan. Hubungan serupa juga terjadi pada arah berbeda, yaitu penurunan kualitas lingkungan saling berkaitan dengan penurunan tingkat pendapatan.

Petani dalam usahataninya tidak hanya berkepentingan dalam meningkatkan produksinya saja, akan tetapi yang lebih penting adalah bagaimana dari peningkatan produksi tersebut dapat meningkatkan pendapatannya yang pada akhirnya juga meningkatkan keuntungannya. Namun kenyataannya dengan semakin menurunnya kualitas lingkungan mengakibatkan penurunan produksi dengan biaya untuk alokasi input yang tidak sebanding, sehingga keuntungan yang didapat juga tidak sesuai dengan harapan para petani padi.

Hal ini disebabkan, untuk meningkatkan produksi dan pendapatannya petani dihadapkan pada berbagai permasalahan, antara lain produktivitas lahan yang menurun karena penggunaan faktor produksi seperti pupuk dan obatobatan dilakukan secara terus menerus sehingga menurunkan kesuburan lahan, luasan lahan yang semakin terbatas, pasokan air yang semakin terbatas, akses untuk berbagai pasokan input lainnya pun semakin bersaing, sementara tetap harus menjadi andalan untuk menciptakan katahanan pangan nasional maka upaya peningkatan produktivitas menjadi utama. Sementara itu munculnya tuntutan baru untuk ramah lingkungan, untuk meningkatkan katahanan terhadap hama dan penyakit, untuk menjaga kesehatan manusia dan lingkungannya, untuk makin toleran terhadap tekanan abiotik seperti perubahan iklim, untuk memenuhi tuntutan konsumen akan kualitas, dan untuk menurunkan ongkos produksi agar lebih 
menguntungkan bagi semua pihak, maka peningkatan produktivitas dengan teroboson atau teknologi baru harus diperkenalkan.

Hal ini diperkuat dengan pendapat beberapa pakar antara lain Debertin (1986) yang menyatakan bahwa suatu teknologi baru biasanya akan memberikan perbaikan dalam hal penggunaan input dalam proses produksi, yaitu : (1) pada penggunaan input yang sama, apabila ada perbaikan dalam penggunaan input maka akan dapat menaikkan marginal produksinya yang baru akan lebih besar dari fungsi produksi yang lama, (2) terjadinya penurunan biaya produksi perunit karena harga dari suatu input atau input lainnya menurun, sehingga menambah keuntungan. Pendapat senada juga disampaikan Semaoen (1992) bahwa perubahan teknologi akan merubah fungsi produksi, tingkat penggunaan input dan tingkat keuntungan.

Dalam upaya untuk meningkatkan produktivitas lahan secara berkelanjutan diperlukan terobosan yang mengarah pada efisiensi usahatani dengan memanfaatkan sumberdaya lokal. Las et al. (1999) menyatakan bahwa dalam meningkatkan produksi padi perlu dilakukan pelestarian lingkungan produksi, termasuk mempertahankan kandungan bahan organik. Oleh karena itu diperlukan suatu teknologi budidaya yang mampu untuk meningkatkan produktivitas lahan secara berkelanjutan.
SRI (System of Rice Intensification) adalah teknik budidaya padi yang mampu meningkatkan produktifitas padi dengan cara mengubah pengelolaan tanaman, tanah, air dan unsur hara. SRI dapat meningkatkan produksi nyata dari 4-6 ton/ha gabah kering panen menjadi 8-12 ton/ha dengan kualitas padi yang dihasilkan lebih baik dengan bertambahnya produk beras kepala dan lebih tahan disimpan. Secara keseluruhan SRI memberikan hasil lebih baik, dalam arti lebih produktif (tanaman lebih tinggi, anakan lebih banyak, malai lebih panjang, dan bulir lebih berat), lebih sehat (tanaman lebih tahan hama dan Penyakit), lebih kuat (tanaman lebih tegar, lebih tahan kekeringan dan tekanan abiotik), lebih menguntungkan (biaya produksi lebih rendah) dan memberikan resiko ekonomi yang lebih rendah (Purwasasmita, 2008).

Melihat tujuan dari petani tersebut sangat sesuai jika sistem SRI diterapkan dalam usahatani padi. Dengan peningkatan produksi dan alokasi biaya yang semakin efisien maka diharapkan memberikan keuntungan dan pendapatan yang meningkat di tingkat petani. Dengan penerapan prinsip-prinsip budidaya padi SRI akan mampu memperbaiki kualitas lingkungan yang menurun sehingga secara berkelanjutan akan membentuk sistem budidaya padi yang mempunyai daya saing dan ramah lingkungan.

Untuk mendapatkan produksi yang maksimum maka petani harus mampu 
mengalokasikan input atau faktor-faktor produksi yang tersedia dengan teknologi tertentu. Pertanyaannya sekarang apakah alokasi input yang telah dilakukan petani padi khususnya didaerah penelitian telah mampu meningkatkan produksi padi? Alokasi input selain berpengaruh terhadap produksi juga berpengaruh terhadap biaya produksi. Dengan menghemat input luar diharapkan dapat menghemat biaya produksi. Permasalahannya adalah apakah dengan alokasi input yang telah dilakukan oleh petani di daerah penelitian sudah mampu meningkatkan pendapatannya? Pertanian berkelanjutan selain memperhatikan tingkat produktivitas, ekuitabilitas, stabilitas juga harus memperhatikan sustainabilitasnya. Faktor keberlanjutan dari sistem pertanian yang dilakukan dapat dilihat dari aspek biofisik seperti tingkat kesuburan tanah (kandungan unsur hara), keremahan tanah (jumlah poripori tanah). Permasalahannya adalah apakah budidaya SRI yang dilakukan oleh petani sudah bisa menjaga kelestarian lingkungan khususnya kesuburan tanah/ lahan?.

\section{Tujuan Penelitian}

1. Mengetahui pengaruh sumberdaya lokal atau faktor-faktor produksi dalam budidaya SRI terhadap produksi padi ( kompos, MOL, bibit, tenaga kerja, air)

2. Mengetahui dampak budidaya SRI terhadap pendapatan petani
3. Mengetahui dampak budidaya SRI terhadap lingkungan dengan indikator kandungan NPK

\section{METODE PENELITIAN}

\section{Lokasi Penelitian}

Lokasi penelitian ditentukan secara sengaja (purpusive) yaitu di Kecamatan Sukorejo Kabupaten Pasuruan. Lokasi penelitian ditentukan di Kecamatan Sukorejo Kabupaten Pasuruan, dimana ada 4 desa yang menerapkan sistem usatani padi SRI yaitu desa Nggunting, Ngadimulyo, Suwayuwo dan Bulukandang

\section{Penentuan Petani Sampel}

Dalam penelitian ini populasi adalah seluruh petani padi yang berada di desa Nggunting, Ngadimulyo, Suwayuwo dan Bulukandang. Sesuai dengan tujuan penelitian maka populasi yang akan diteliti dibagi 2 kelompok yaitu: populasi petani padi yang menggunakan sistem SRI dan populasi petani yang Non SRI. Penentuan sampel secara keseluruhan berpedoman pada pendapat pakar sampling bahwa untuk mendapatkan data yang representatif, sekurang-kurangnya adalah $10 \%$ dari populasi yang ada dan juga dikatakan tidak ada aturan yang tegas tentang jumlah sampel yang dipersyaratkan untuk suatu penelitian dari populasi yang tersedia (Singarimbun 1989). 


\section{Metode Analisis Data}

Model empiris yang digunakan untuk menganalisis dan menguji hipotesis dalam penelitian ini adalah mengestimasiannya dengan metode SUR (Seemingly Unrelated Regression ) dan metode kuadrad terkecil sebagai pembanding. Untuk menguji hipotesis ke-3 yaitu untuk mengetahui dampak penerapan budidaya Padi secara SRI terhadap kesuburan tanah digunakan uji lab terhadap sampel tanah yang SRI dan Non SRI. Uji lab dilakukan untuk mengetahui kandungan N,P,K dan jumlah pori-pori tanah. Hasil uji lab kemudian ditabulasi dan dianalisis menggunakan analisis regresi untuk mngetahui dampak budidaya padi SRI terhadap kandungan NPK.

\section{HASIL DAN PEMBAHASAN}

Penggunaan Input pada Usahatani Padi

\section{SRI dan Non SRI}

Tingkat rata-rata penggunaan input luas lahan, curahan tenaga kerja luar keluarga dan dalam keluarga, benih, pupuk anorganik, obat, kompos, mol serta produksi padi dikemukakan pada tabel 1 sebagai berikut:

Tabel 1. Rata-rata Produksi dan Penggunaan Input pada Usahatani Padi SRI dan Non SRI (per hektar)

\begin{tabular}{l|l|r|r}
\hline No & Jenis Input & Usahatani & \multicolumn{1}{l}{ Usahatani } \\
\hline & & SRI & \multicolumn{1}{l}{ Non SRI } \\
\hline 1 & Lahan (ha) & 0,41 & 0,5 \\
\hline 2 & Tenaga Kerja (HKSP/ha) & 34,202 & 34,527 \\
\hline & Dalam Keluarga & 73,547 & 73,948 \\
\hline & Luar Keluarga & 7,134 & 60,489 \\
\hline 3 & Benih $(\mathrm{kg} / \mathrm{ha})$ & 261,427 & 352,932 \\
\hline 4 & Urea $(\mathrm{kg} / \mathrm{ha})$ & 261,427 & 152,216 \\
\hline 5 & SP-36 $(\mathrm{kg} / \mathrm{ha})$ & 123,263 & 152,216 \\
\hline 6 & Ponska $(\mathrm{kg} / \mathrm{ha})$ & 94,052 & 96,88 \\
\hline 7 & Pestisida (ml/ha) & 122,1157 & 189,513 \\
\hline 8 & Kompos (ton/ha) & 3,634 & 0 \\
\hline 9 & Mol (lt/ha) & 57,666 & 0 \\
\hline 10 & Produksi $(\mathrm{kg} / \mathrm{ha})$ & $7.049,353$ & $4.519,621$ \\
\hline
\end{tabular}

Sumber : data primer yang diolah 2013

Dari tabel 1 dapat dilihat bahwa penggunaan rata-rata input pada usahatani padi SRI lebih kecil dibandingkan pada usahatani Non SRI khususnya pada penggunaan benih dan pupuk anorganik. Hal ini sesuai apa yang terjadi dilapang bahwa penggunaan benih SRI disesuaikan sistem tanamnya yaitu tanam satu bibit per lubang dan jarak tanam yang lebih lebar sehingga benih yang dibutuhkan lebih sedikit. Pada penggunaan pupuk anorganik pada sistem usahatani padi SRI penggunaan pupuk anorganik lebih sedikit karena dikombinasikan dengan pupuk organik yang berupa kompos dan MOL. Hal ini 
sesuai harapkan dari prinsip SRI yang menganjurkan pengurangan penggunaan pupuk anorganik dan perlahan beralih ke pupuk organik dalam hal ini adalah kompos dan MOL. Namun rata-rata penggunaan pupuk anorganik melebihi dosis pupuk anjuran. Dosis anjuran untuk SRI $200 \mathrm{~kg} / \mathrm{ha}$ Urea; 50 kg/ha SP26; 100 kg/ha Ponska, jika ditotal dosis anjuran pupuk anorganik adalah $350 \mathrm{~kg} / \mathrm{ha}$. Dosis anjuran Non SRI 200 kg/ha Urea; 100 kg/ha SP26; 100 kg/ha Ponska, jika ditotal dosis anjuran pupuk anorganik adalah $400 \mathrm{~kg} / \mathrm{ha}$.

Untuk pemakaian tenaga kerja dalam keluarga dan luar keluarga, curahan tenaga kerja SRI lebih banyak, perbedaan ini disebabkan pada usahatani SRI tidak memerlukan tenaga cabut benih (daud) yang rata-rata dikerjakan 2-3 orang laki-laki selama 2-3 hari/hektar dan pada kegiatan persemaian bisa dilakukan sendiri tanpa tenaga kerja luar keluarga karena persemaian ditempatkan pada besek dan dilakukan dirumah. Sedangkan pada usahatani Non SRI persemaian dilakukan di sawah dan memerlukan tenaga kerja luar keluarga rata-rata 2-3 orang pria selain itu untuk pemupukan pada usahatani Non SRI memerlukan tenaga luar keluarga yang lebih banyak daripada usahatani padi SRI yang rata-rata selisihnya sampai dua orang pria. Namun proporsi pengurangan tenaga kerja di kegiatan persemaian dan pemupukan pada usahatani SRI belum sebanding dengan kegiatan penanaman dan perawatan. Kegiatan perawatan pada sistem SRI lebih intensif sehingga memerlukan tenaga kerja yang lebih banyak. Contohnya adalah kegiatan penanaman, karena tenaga kerja tanam belum banyak yang trampil dalam menanam satu lubang satu bibit sesuai prinsip tanam SRI maka pekerjaannya lebih lambat dan memerlukan waktu yang lebih lama sehingga petani sering menambah tenaga kerja untuk mempercepatnya. Kegiatan lain yang memerlukan tenaga kerja lebih banyak adalah penyiangan. Pada sistem SRI penyiangan dilakukan 3 - 4 kali sedangkan pada Non SRI bisa dilakukan 2 kali. Hal ini disebabkan sistem tanam yang lebar menyebabkan terdapat banyak gulma (rumput/alang-alang) sehingga perlu adanya penyiangan yang lebih sering. Selain itu untuk mengatur air pada sistem SRI membutuhkan waktu yang banyak dan biasanya dilakukan oleh tenaga kerja dalam keluarga. Berdasarkan uraian ini bisa menjelaskan mengapa tenaga kerja yang dibutuhkan SRI bisa lebih banyak daripada Non SRI. Hal ini didukung hasil penelitian Anugrah (2008) yang mengatakan bahwa pemakaian teaga kerja cara SRI lebih banyak dibandingkan cara Non SRI, perbedaan ini disebabkan oleh kegiatan yang lebih intensif dalam pengendalian gulma, pengairan dan penanaman.

Aplikasi pemberian pupuk kompos baik petani SRI dan Non SRI masih dibawah anjuran, hal ini disebabkan petani 
dalam menentukan dosis kompos berdasarkan ketersediaan bahan baku kompos yaitu kotoran ternak (padat). Pada petani SRI karena mendapat penyuluhan dan pelatihan kesuburan tanah, maka wawasan terhadap kesuburan tanah bertambah. Oleh karena itu dosis pupuk kompos yang diberikan lebih banyak daripada petani Non SRI.

Petani Non SRI dalam budidaya padi tidak menggunakan MOL. Hal ini disebabkan petani Non SRI belum mengikuti pelatihan dan penyuluhan yang diadakan didaerah penelitian tentang pembuatan dan kegunaan MOL. Produksi yang dihasilkan antara petani SRI dan Non SRI sangat berbeda. Petani SRI di daerah penelitian dapat menghasilkan gabah kering panen rata-rata sebesar $7.049,353 \mathrm{~kg} / \mathrm{ha}$ sedangkan pada petani Non SRI rata-rata dapat menghasilkan 4.519,621 kg/ha. Perbedaan hasil ini dipengaruhi oleh sistem tanam dan pemupukan. Sistem tanam tunggal menyebabkan anakan lebih banyak sehingga hasil yang didapat juga lebih banyak. Pemberian pupuk kompos dan MOL juga mempengaruhi perbedaan hasil ini. Menurut beberapa penelitian tentang pengaruh kompos terhadap produktivitas padi antara lain Thamrin (2000) menerangkan bahwa pemberian pupuk kandang mampu meningkatkan hasil gabah kering panen secara nyata begitu juga Igbal (2008) menyatakan bahwa pupuk kandang dengan takaran 50 persen anjuran mempengaruhi jumlah dan berat gabah/tanaman secara nyata.

\section{Biaya Penggunaan Input Produksi}

Tabel 2. Rata-rata Perhektar Biaya Produksi Usahatani Padi Pada Masing-masing Kelompok Usahatani Padi

\begin{tabular}{|c|c|c|c|}
\hline NO & Jenis Input & Usahatani (Rp) & Usahatani (Rp) \\
\hline & & SRI & Non SRI \\
\hline \multirow[t]{3}{*}{1} & Tenaga Kerja (HKSP/ha) & & \\
\hline & Luar Keluarga & $463.741,964$ & 684449,5536 \\
\hline & Dalam Keluarga & $989.711,6$ & 1509694 \\
\hline 3 & Benih (kg/ha) & $23.101,88$ & 308040,8 \\
\hline 4 & Urea $(\mathrm{kg} / \mathrm{ha})$ & $196.070,1$ & 423733,7 \\
\hline 5 & SP-36 (kg/ha) & $123.263,7$ & 243546,6 \\
\hline 6 & Ponska (kg/ha) & 111.687 & 172763,6 \\
\hline 7 & Pestisida (ml/ha) & $15.807,07$ & 25021,49 \\
\hline 8 & Kompos (ton/ha) & 1.135 .268 & 0 \\
\hline 9 & Mol (lt/ha) & $180.203,3$ & 0 \\
\hline \multirow[t]{2}{*}{10} & Biaya Penyusutan alat & $29.660,71$ & 0 \\
\hline & total & $3.268 .515,324$ & $3.367 .249,744$ \\
\hline
\end{tabular}

Sumber : data primer yang diolah 2013

Biaya rata-rata pada usahatani padi SRI lebih besar dari pada usahatani Non
SRI, hal ini disebabkan pada usahatani SRI biaya yang tinggi diperlukan untuk upah 
tenaga kerja luar keluarga, kompos dan MOL. Sedangkan usahatani SRI mampu menghemat biaya benih dan pupuk anorganik. Biaya tenaga kerja yang lebih besar dikarenakan cara SRI lebih banyak tenaga kerja luar keluarga yang dibutuhkan, hal ini sesuai dengan penelitian Wardana (2005) yang menjelaskan bahwa biaya produksi SRI di Kabupaten Garut lebih tinggi pada biaya tenaga kerja luar keluarga. Di tingkat petani biaya kompos dan MOL tidak diperhitungkan secara benar. Hal ini dikarenakan untuk mendapatkan kompos sebagian dari mereka tidak membeli karena punya ternak sendiri dan sebagian lagi mendapatkan kompos dari sesama petani namun biaya angkutnya belum diperhitungkan. Untuk mendapatkan MOL sebagian petani membuatnya secara berkelompok dengan bahan baku ditanggung bersama dan sebagian lagi (urin ternak) dan ada beberapa petani untuk mendapatkan MOL dengan membeli pada petani lain yang sudah sukses membuatnya. Oleh karena itu, untuk keseragaman dalam perhitungan biaya maka harga kompos dan harga MOL dalam penelitian ini diperhitungkan (Rp). Perbedaan biaya usahatani ini sesuai dengan pendapat Anugrah (2008) bahwa jika dikaji secara benar biaya SRI akan lebih besar daripada biaya Non SRI. Perbedaan ini terlihat pada biaya tenaga kerja luar keluarga, biaya kompos dan MOL.

\section{Hasil Pendugaan Persamaan Produksi dan Penggunaan input Pada Usahatani Padi SRI}

Analisis pada produksi dan penggunaan input pada usahatani padi SRI dilakukan dengan menganalisis persamaan perilaku dalam ekonomi produksi dengan melihat berdasarkan kreteria ekonomi dan statistik. Secara keseluruhan model perilakunya menujukkan hasil yang baik yang memenuhi kreteria baik secara ekonomi maupun statistik. Secara ekonomi tanda dan besaran pada setiap persamaan bisa menjelaskan fenomena yang ada. Nilai koefisien determinasi $\left(\mathrm{R}^{2}\right)$, nilai F-hitung dan nilai probabilitas $F$ (Uji F) serta $T$ hitung dan probabilitas $\mathrm{T}$ (Uji-T) yang merupakan kreteria statistik secara keseluruhan juga menunjukkan hasil yang baik pada masing-masing persamaan.

Hasil uji $F$ secara keseluruhan juga menunjukkan bahwa seluruh variabel yang menyusun model secara bersama-sama berpengaruh terhadap variabel endogen pada taraf nyata $1 \%$.

\section{Pengaruh Budidaya SRI dan Non SRI} Terhadap Pendapatan dan hasil produksi usahatani padi

Analisis ini menggunakan uji beda rata-rata untuk mengetahui apakah pendapatan dan hasil produksi usahatani padi dengan menggunakan SRI lebih besar dari pada usahatani padi Non SRI. 
Tabel 3. Hasil Pengujian Probabilitas F pada analisis produksi dan Penggunaan input

\begin{tabular}{l|l|l}
\hline No & Persamaan & Prob-F \\
\hline 1. & Tenaga kerja luar keluarga & 0,0001 \\
\hline 2. & Benih & 0.0001 \\
\hline 3. & Pupuk anorganik & 0,0001 \\
\hline 4. & Kompos & 0,0001 \\
\hline 5. & MOL & 0,0001 \\
\hline 6. & Produksi $\quad 0,0001$ \\
\hline \multicolumn{2}{c}{ Rata-rata } & 0,0001
\end{tabular}

Sumber : Hasil Analisis 2010

Tabel 4. Uji Beda Rata-rata Pendapatan dan Produksi SRI dan Non SRI

\begin{tabular}{l|l|l|l|l|l}
\hline Variabel & \multicolumn{2}{|c|}{ Rata-rata Hasil } & & T hit & Prob \\
\cline { 2 - 6 } & SRI & Non SRI & Perbedaan & & \\
\hline Pendapatan Bersih (Rp) & 11.936 .675 & 5.961 .559 & 7.416 .938 & 0,876 & 0,0001 \\
\hline Produksi (kg) & $7.049,353$ & $4.519,621$ & $2.529,732$ & 0,968 & 0,0001 \\
\hline
\end{tabular}

Sumber : data diolah 2013

Dari tabel 4 dapat disimpulkan bahwa

pertama adalah dengan metode OLS. rata-rata pendapatan per hektar petani SRI lebih besar daripada petani Non SRI. Perbedaan ini secara statistik nyata pada tingkat signifikansi $1 \%$. Rata-rata produksi SRI lebih besar dari pada Non SRI. Hal ini dapat dilihat secara statistik yang menunjukkan bahwa tingkat sig $=0,0001$. Perbedaan pendapatan ini disebabkan jumlah produksi pada usahatani SRI lebih tinggi sehingga penerimaannya lebih besar meskipun dilihat dari segi biaya selisihnya hanya sedikit.

\section{Faktor-Faktor yang berpengaruh terhadap Pendapatan Usahatani Padi SRI.}

Analisis faktor-faktor yang berpengaruh terhadap pendapatan usahatani padi SRI dilakukan dengan metode ordinary least Square (OLS) dan seemingly Unrelated Regression (SUR). Metode Metode kedua adalah metode SUR I, yaitu pendugaan dengan metode SUR tanpa restriksi (fungsi keuntungan maksimum). Hasil analisis menunjukkan bahwa hasil pendugaan terhadap ketiga metode yang digunakan, masing-masing mempunyai nilai $\mathrm{F}$ hitung yang lebih besar dari $\mathrm{F}$ tabel dengan taraf nyata pada tingkat kepercayaan 99\%, yang mengindikasikan bahwa spesifikasi variabel yang dijelaskan dan variabel penjelas yang dimasukkan dalam model sudah dianggap tepat dan dapat diandalkan. Pada nilai $F$ tersebut dapat juga disimpulkan bahwa semua variabel independent (input) yang dimasukkan dalam model secara bersamasama mempengaruhi variabel dependent (keuntungan).

Koefisien determinasi (R2) pada semua metode lebih besar dari $80 \%$, artinya bahwa ketiga metode tersebut telah mampu 
menjelaskan keragaman total dari variabel dependent (keuntungan) dengan proporsi atau persentase yang tinggi dan sisanya disebabkan oleh faktor lain di luar model yang dibangun.

Uji multikolinieritas dilakukan dengan melihat matrik korelasi antar variabel bebsa yang dianalisis pada ketiga metode tersebut.

Untuk melihat metode yang paling baik, dalam penelitian ini dilakukan uji perbandingan R2 dan standart error yang diperoleh pada masing-masing metode. Pendugaan metode II (SURI) nampak lebih baik dibandingkan metode I OLS. Hal ini dapat dilihat pada nilai koefisien dterminasinya. Pendugaan fungsi keuntungan pada metode I OLS mempunyai nilai koefisien determinasi (R2) sebesar $88,99 \%$. Koeifisien determinasi 88,99\% artinya bahwa model fungsi keuntungan (variabel independent) mampu menjelaskan sekitar $88,99 \%$ dari keragaman total kuantitas keuntungan (UOP), sedangkan sisanya sebesar $11,01 \%$ dijelaskan oleh faktor lain yang tidak terdapat di dalam model. Pada metode II (SUR I) mempunyai nilai koefisien determinasi (R2) lebih besar daripada metode I yaitu sebesar 90,48\%, menunjukkan bahwa penggunaan metode II akan memberikan hasil estimasi yang lebih bisa diandalkan.

Dilihat dari taksiran parameter yang tidak bias, dalam hal ini kriteria kesalahan baku (standart errors), pendugaan metode II (SURI) juga nampak lebih baik dibandingkan dengan metode I (OLS). Hal ini terbukti dari nilai standart error pada metode II untuk semua parameter yang dihitung teryata lebih baik dibandingkan dengan metode I, sehingga memberikan tingkat signifikansi yang lebih baik. Kenyataan ini memberikan indikasi bahwa pendugaan secara simultan terhadap dua persamaan yang berbeda denngan menggunakan metode SUR memberikan hasil yang lebih baik dibandingkan dengan metode lainnya. Oleh karena itu selanjutnya yang akan dibahas adalah metode II (dengan metode SUR I).

Hasil pendugaan pada metode SUR II (fungsi keuntungan maksimum) memberikan nilai koefisien determinasi (R2) yang cukup tinggi, yaitu 99,73\% yang berarti bahwa $99,73 \%$ variasi tingkat keuntungan maksimum jangka pendek dapat dijelaskan oleh variasi input yang termasuk dalam model.

Variabel input yang berpengaruh nyata terhadap pendapatan adalah harga pupuk anorganik, harga kompos dan upah TKLK (tenaga kerja luar keluarga). Harga pupuk anorganik berpengaruh pada taraf kepercayaan 90\%, sedangkan upah tklk berpengaruh nyata dengan taraf kepercayaan sebesar 99\%. Keofisien regresi harga pupuk anorganik adalah -0,146 artinya jika harga pupuk anorganik naik $10 \%$ maka pendapatan akan turun $1,46 \%$ (cetris paribus). Koefisen regresi upah tklk adalah $-0,260$ artinya jika upah tklk naik 
10\% maka akan menurunkan pendapatan sebesar 2,60\% (ceteris paribus).

Penggunaan input tklk untuk memperoleh produksi yang maksimum terlalu banyak, sehingga menyebabkan terjadinya penurunan pada pendapatan yang diperoleh. Jumlah tklk yang digunakan akan menjadi banyak karena usahatani ini memerlukan pekerjaan yang lebih intensif dari pada usahatani biasa. Pupuk anorganik meskipun sudah dikurangi dengan kompos namun harga tetap mempengaruhi pendapatan usahatani karena petani dalam penggunaannya tidak sesuai dosis anjuran.

Input harga kompos juga berpengaruh nyata dengan taraf kepercayaan sebesar 95\%, akan tetapi nilai koefisien regresinya positif sebesar 0,234. Artinya penambahan kompos akan menyebabkan peningkatan pada produksi sehingga pendapatan juga akan meningkat.

\section{Pengaruh Usahatani Budidaya SRI terhadap Kandungan NPK Tanah}

Dilihat dampak dari usahatani SRI terhadap kandungan NPK tanah bisa dilihat dari tabel 5. Dari tabel tersebut dapat dilihat adanya perbedaan kandungan tanah usahatani yang memakai teknologi SRI dan yang tidak (NON SRI). Pada lahan yang telah menerapkan budidaya SRI lebih dari 4 kali musim tanam atau berkisar 1 tahun lebih menunjukkan kandungan $\mathrm{N}$ oragnik yang tinggi yaitu 0,638 berkisar antara 0,51-0,75 sedangkan NON SRI 0,1159 yaitu rendah atau berkisar antara 0,1-0,2. Ini jelas menunjukkan bahwa budidaya SRI dapat memperbaiki kandungan nutrisi tanah yang sangat bermanfaat terhadap tanaman. Budidaya SRI menekankan pada cara bertanam satu, sedikit air dan penambahan pupuk kompos. Menurut Kartaseputro (1987) pupuk kandang merupakan salah satu pupuk organik yang dapat memberikan tambahan hara, disamping dapat memperbaiki sifat fisik dan biologis tanah serta dapat mengembalikan unsur hara yang terangkut hasil panen. Selain itu juga dapat mencegah kehilangkan air dalam tanah dan laju inflasi air. Pengaruh yang lebih menguntungkan dari pupuk kandang dibandingkan pupuk buatan lainnya adalah dapat memperbiki sifat fisik tanah, kimia dan biologis tanah, merangsang pertumbuhan mikroorganisme tanah serta dapat menyediakan unsur N, P, K. 
Tabel 5. Hasil Analisis Tanah NPK Usahatani SRI dan NON SRI

\begin{tabular}{l|c|c|c}
\hline \multirow{2}{*}{ SAMPEL } & BAHAN ORGANIK & P2O5 OLSEM & $\mathrm{K}$ \\
\hline Rata-rata SRI & 0,638 & 30,26 & 0,862 \\
\hline Rata-rata NON SRI & 0,1159 & 23,613 & 0,6 \\
\hline Rendah sekali & $<0,1$ & $<5$ & 0,1 \\
\hline Rendah & $0,1-0,2$ & $5-10$ & 0,3 \\
\hline Sedang & $0,21-0,5$ & $11-15$ & 0,5 \\
\hline Tinggi & $0,51-0,75$ & $16-20$ & $0,6-1,0$ \\
\hline Tinggi sekali & $>0,75$ & $>20$ & $>1,0$ \\
\hline
\end{tabular}

Sumber : Hasil analisis laboratorium 2013

Menurut Gardner. G (1996), suatu sistem pertanian itu bisa disebut berkelanjutan jika memiliki sifat-sifat sbb:

1. Mampertahankan fungsi ekologis, artinya tidak merusak ekologi pertanian itu sendiri

2. Berlanjut secara ekonomis artinya mampu memberikan nilai yang layak bagi pelaksana pertanian itu dan tidak ada pihak yang diekploitasi. Masing-masing pihak mendapatkan hak sesuai dengan partisipasinya

3. Adil berarti setiap pelaku pelaksanan pertanian mendapatkan hak-haknya tanpa dibatasi dan dibelunggu dan tidak melanggar hal yang lain

4. Manusiawi artinya menjunjung tinggi nilai-nilai kemanusiaan, dimana harkat dan martabat manusia dijunjung tinggi termasuk budaya yang telah ada
5. Luwes yang berarri mampu menyesuaikan dengan situasi dan kondisi saat ini, dengan demikian pertanian berkelanjutan tidak statis tetapi dinamis bisa mengakomodir keinginan konsumen maupun produsen.

Beberapa kegiatan yang dilakukan pada budidaya SRI diharapkan dapat menunjang dan memberikan kontribusi dalam meningkatkan keuntungan, produktivitas pertanian dalam jangka panjang, meningkatkan kualitas lingkungan, serta meningkatkan kualitas hidup masyarakat tani.

Berdasarkan penjabaran yang telah dijelaskan sebelumnya, maka dapat disimpulkan bahwa usahatani padi dengan menerapkan budidaya SRI merupakan salah satu teknologi alternatif pertanian yang memberikan berbagai hal positif, yang dapat diterapkan pada usaha tani padi, sehingga produk-produk hasil pertanian dapat bernilai komersial tinggi, menjamin 
pemenuhan kebutuhan pangan dan keamanan pangan, dan dapat memberikan kesadaran masyarakat dan petani khususnya dalam melestarikan ekosistem lingkungan. Oleh karena itu, untuk menerapkan sistem pertanian ramah lingkungan yang harmonis dan berkelanjutan perlu dilakukan. Perlu ditekankan bahwa usaha tani yang berorientasi pasar global perlu menekankan aspek kualitas, keamanan, kuantitas dan harga yang bersaing. Semua hal ini dipenuhi dalam usahatani padi dengan menerapkan teknologi budidaya padi SRI.

\section{KESIMPULAN DAN SARAN}

\section{Kesimpulan}

Dari pelaksanaan penelitian ini dapat disimpulkan bahwa :

a. Faktor-faktor produksi yang berpengaruh pada usahatani padi dengan budidaya SRI adalah tenaga kerja dalam keluarga (TKDK), tenaga luar keluarga (TKDL), bibit, kompos, MOL dan pupuk anorganik.

b. Budidaya padi SRI memberikan keuntungan yang signifikan, rata-rata pendapatan per hektar petani SRI lebih besar daripada petani Non SRI. Perbedaan ini secara statistik nyata pada tingkat signifikansi $1 \%$. Ratarata produksi SRI lebih besar dari pada Non SRI. Hal ini dapat dilihat secara statistik yang menunjukkan bahwa tingkat sig $=0,0001$. Perbedaan pendapatan ini disebabkan jumlah produksi pada usahatani SRI lebih tinggi sehingga penerimaannya lebih besar meskipun dilihat dari segi biaya selisihnya hanya sedikit.

c. Dilihat dampak dari usahatani SRI terhadap kandungan NPK tanah ada perbedaan kandungan tanah usahatani yang memakai teknologi SRI dan yang tidak (NON SRI). Pada lahan yang telah menerapkan budidaya SRI lebih dari 4 kali musim tanam atau berkisar 1 tahun lebih menunjukkan kandungan $\mathrm{N}$ oragnik yang tinggi yaitu 0,638 berkisar antara 0,51-0,75 sedangkan NON SRI 0,1159 yaitu rendah atau berkisar antara 0,1- 0,2. Ini jelas menunjukkan bahwa budidaya SRI dapat memperbaiki kandungan nutrisi tanah yang sangat bermanfaat terhadap tanaman.

\section{Saran}

a. Disarankan kepada petani padi bahwa dalam menerapkan budidaya padi SRI haruslah memperhatikan petunjuk tenis khususnya pada penggunaan pupuk buatan (anorganik) agar sesuai kebutuhan atau dosis tanaman. Dengan begitu akan mengefisienkan penggunaan biaya dan tanah akan terjaga dari ketersediaan unsur hara

b. Budidaya SRI dapat dilakukan di tempat yang kondisi pengairannya kurang, dengan menggunakan sumberdaya lokal untuk pupuk akan menambah produktifitas lahan. 


\section{DAFTAR PUSTAKA}

Departemen Pertanian Indonesia, 2008. Pusat Data dan Informasi Departemen Pertanian. Jakarta.

Anugrah.2008. Gagasan dan Implementasi System of Rice Intensification (SRI) Dalam Kegiatan Budidaya Padi Ekologis. Jurnal Analisis Kebijakan Pertanian Vol 6 No.1 2008:75-99.

Beattie BR dan Taylor, 1996, The Economic of Production (Ekonomi Produksi)

Terjemahan Josohardjono, Penyunting G. Sumodiningrat. Gajah Mada University Press, Yogyakarta.

BPS.2009. Biro Pusat Statistik Kabupaten Pasuruan. Pasuruan.

Debertin, David L. 1986. AgriculturalProduction

Economics. Collier Macmillan Publishers. London

Gardner, G. 1996. Presserving agricultural resources. Dalam : State of the World. W.W narton \& Company. New York. H 78-94

Karwan A. Salikin. 2003. Sistem Pertanian Berkelanjutan. Kanisius. Yogyakarta.

Kasyono, F. 1995. Prospek Pertanian Indonesia dan Antisipasi dalam Menghadapi Persaingan Global. Makalah disampaikan pada Pertemuan Teknis di P3GI Pasuruan.

Kusharto, M dan Guhardja, S.1996. Pembangunan Pertanian yang Berwawasan Kesuma dalam Gizi dan Kesehatan dalam Pembagunan Pertanian. IPB Press. Bogor
Las, I., A.K. Makarim, Sumarno, S. Purba, M. Mardikarini, dan S. Kartaatmadja. 1999. Pola IP padi300, konsepsi dan prospek implementasi system usaha pertanian berbasis sumberdaya. Badan Litbang Pertanian Hal 66.

Libunao, W.H.1995. Sustainable Agriculture Indicator: an NGO Perspective. Dalam: Paper Presented During the Workshop on Sustainable Agriculture Indicator held on 29-30 May 1995 at SEARCA College, Laguna, Philippines.

Mubyarto, 1984. Politik Pertanian dan Pengmbangan Pedesaan. Pustaka Sinar Harapan, Cetakan Kedua. Jakarta

Mutakin, 2008. Budidaya dan Keunggulan Padi Organik SRI (System of Rice Intensification). Pertanian Ekologis. Yayasan Field Indonesia.

Purwasasmita, M. 2007. Tanah sebagai Bioreaktor Landasan System Of Rice Intensification. Seminar Teknik Kimia Suhadi Reksowardoyo. Bandung.

Singarimbun, Masri dan Sofian Effendi. 1995. Metode Penelitian Survey. LP3ES, Jakarta.

Soekartawi, 1987. Prinsip Dasar Ekonomi Produksi. Teori dan Aplikasinya. CV Rajawali Jakarta.

2006. Teori Ekonomi Produksi dengan Pokok Bahasan Analisis Fungsi Cobb-Douglas. Rajawali. Jakarta.

Semaoen, Iksan. 1992. Ekonomi Produksi Pertanian: Teori dan Aplikasi. Ikatan Sarjana Ekonomi Indonesia (ISEI) Cabang Jakarta. Jakarta. 